\title{
Caudal vena cava thrombosis in a dairy cow (Bos taurus) in Argentina
}

\author{
Carlos Schild ${ }^{1,2^{*}}$ Joaquín Ignacio Armendano ${ }^{1,3}$ Matías Liboreiro ${ }^{1,4}$ Florencia Bresky $^{1}$ \\ Eleonora Morrell ${ }^{1}$ Ernesto Odriozola ${ }^{1}$ Germán Cantón $^{1}$
}

\begin{abstract}
${ }^{1}$ Grupo de Sanidad Animal, Instituto Nacional de Tecnologia Agropecuaria (INTA), Estación Experimental Agropecuaria (EEA), Balcarce, Buenos Aires, Argentina.

${ }^{2}$ Plataforma de Salud Animal, Instituto Nacional de Investigación Agropecuaria (INIA), 7000, La Estanzuela, Colonia, Uruguay. E-mail: schild.co@gmail.com. *Corresponding author.

${ }^{3}$ Facultad de Ciencias Agrarias, Universidad Nacional de Mar Del Plata, Buenos Aires, Argentina.

${ }^{4}$ Profesional de Ejercicio Liberal, Buenos Aires, Argentina.

ABSTRACT: Caudal vena cava thrombosis (CVCT) is an acute disease secondary to ruminal lactic acidosis and rumenitis with fatal outcome in cattle fed with a high-grain diet. The aim of this paper is to describe CVCT in an adult Holstein cow from a herd in Balcarce, Buenos Aires, Argentina. Clinical signs included dyspnea, weakness, recumbence, and hemoptysis, followed by death in 3.5 days. Important necropsy findings included multiple hepatic abscesses, a septic thrombus $(4.0 \mathrm{~cm} \times 2.0 \mathrm{~cm})$ in the vena cava adjacent to the liver, and a $15 \mathrm{~cm}$ hematoma in the right lung. Histological lesions observed in the pulmonary parenchyma included suppurative pneumonia with embolic bacterial colonies and severe interstitial fibroplasia. Dissociation and degeneration of elastic fibers were observed in the pulmonary arteries, and necrotizing vasculitis was present in the caudal vena cava. We concluded that CVCT should be included in the differential diagnosis of diseases with acute respiratory signs. The preventive measures to control the CVCT include the reduction of lactic acidosis.

Key words: cattle, Holstein, thrombosis, vena cava, hemoptysis.
\end{abstract}

Trombose da veia cava caudal em uma vaca leiteira (Bos taurus) na Argentina

RESUMO: A trombose da veia cava caudal (TVCC) é uma doença aguda, letal, secundária à acidose láctica ruminal e rumenite, em gado alimentado com dieta rica em grãos. O objetivo deste artigo é descrever um caso de TVCC em uma vaca de um rebanho leiteiro Holstein localizado em Balcarce, Buenos Aires, Argentina. Os sinais clínicos observados foram dispneia, fraqueza, decúbito, hemoptise e morte dentro de 3 1 1/2 dias. Os principais achados de necropsia foram múltiplos abscessos hepáticos, um trombo séptico de $4.0 \mathrm{~cm} \times 2.0 \mathrm{~cm}$ na veia cava caudal adjacente ao figado e um hematoma de $15 \mathrm{~cm}$ de diâmetro no pulmão direito. As lesões histológicas observadas no parênquima pulmonar foram pneumonia embólica supurativa com colonias de bactérias e fibroplasia intersticiais graves; na túnica adventicia das artérias pulmonares observou-se degeneração e dissociação das fibras elásticas e na veia cava caudal havia vasculite necrosante. A TVCC deve ser incluído no diagnóstico diferencial de doenças com sinais respiratórios agudos. É necessário estabelecer medidas preventivas para reduzir a acidose láctica e controlar a TVCC.

Palavras-chave: gado, Holstein, trombose, veia cava, hemoptise.

CVCT is a disease that affect dairy (GUDMUNDSON et al., 1978) and feedlot cattle (JENSEN et al., 1976). A CVCT is usually diagnosed in adult cattle; although, it can occur in young animals, it is rare in calves under one year of age (BRAUN, 2008). The main predisposing factors are adult cattle fed with high-concentrate diets and the consequent ruminal lactic acidosis and rumenitis (WOOLUMS, 2015). Rumenitis allows penetration of bacteria such as Fusobacterium necrophorum, Trueperella pyogenes (IKAWA et al., 1987), Streptococcus spp., Staphylococcus spp. and Escherichia coli, among others (CONSTABLE et al., 2017a). Other conditions, such as deep digital sepsis (SIMPSON et al., 2012), mastitis, or metritis (BRAUN, 2008; WOOLUMS,
2015) can also result in CVCT. Omphalophlebitis (GUDMUNDSON et al., 1978) and abomasal ulcers (DIVERS \& PEEK, 2008a) are the most common causes of CVCT in young animals.

CVCT is associated with rupture of hepatic abscesses, inflammation extending into the hepatic vein or the caudal vena cava, formation of a septic thrombus, and is the cause of multiple septic emboli in the pulmonary capillaries (MILLER \& GAL, 2017).

Clinical signs include dyspnea, tachypnea, hyperpnea, cough, pale mucous membranes, tachycardia, rales, and expiratory wheezing; the clinical course of the disease typically extends 2-18 days. Hemoptysis and epistaxis indicate a poor prognosis; death usually follows within 24-48 hours (BREEZE 
et al., 1976; MILLS \& PACE 1990; BRAUN, 2008; WOOLUMS, 2015). During the postmortem examination, hepatic abscesses are present and CVCT is observed. Pulmonary hematomas can be observed around a ruptured aneurysm, along with pulmonary edema, emphysema, hemorrhages, and abscesses (BREEZE et al., 1976; GUDMUNDSON et al., 1978; BRAUN, 2008; WOOLUMS, 2015; CONSTABLE et al., 2017a). This paper described a case of CVCT in a Holstein cow in Argentina.

The case occurred in May 2014 in a 350-ha dairy farm with 350 Holstein cows located near Balcarce, in the Buenos Aires province, Argentina. Milking cows grazed alfalfa (Medicago sativa), winter fodder crops (Lolium multiflorum and Avena sativa), and were fed with ground corn and wheat grains, sunflower meal, and vitamin and mineral supplements. A sixth lactation cow in good body condition developed signs of weakness over 3 days. Subsequently severe dyspnea, hemoptysis, and epistaxis occurred. Death occurred 8-12h after developing hemoptysis-epistaxis. A postmortem examination was performed, and tissue samples were collected in $10 \%$ buffered formalin solution for histopathological analysis (hematoxylin and eosin staining). Only selected tissue sections were Gram stained.

At necropsy, the cow was in good body condition with significant fat deposition. Multiple random abscesses, 2.0 to $5.0 \mathrm{~cm}$ in size, were disseminated throughout the liver. A $4.0 \times 2.0 \mathrm{~cm}$ septic thrombus was reported in the hepatic portion of the caudal vena cava (Figure 1A). A portion of the right lung was enlarged and firm, white petechiae and interlobar edema. A hematoma, $15.0 \mathrm{~cm}$ in diameter, was reported in the cranial region of the middle right lobe, which was associated with a ruptured fusiform aneurysm $3.0 \mathrm{~cm}$ in diameter (Figure 1B). The pulmonary parenchyma surrounding the hematoma had multiple randomly spaced abscesses 2.0 to $6.0 \mathrm{~cm}$ in size, widely distributed hemorrhages, and interstitial edema. Multiple blood clots were reported in the oral cavity, nasal passages, trachea, and rumen. Microscopically, the caudal vena cava had focally extensive, necrosuppurative, chronic-active phlebitis in the intima and adventitia (Figure 1C). Lung had suppurative pneumonia with the presence of embolic thrombi and intra-alveolar colonies of gram negative bacilli and coccobacilli (Figure 1D); severe interstitial fibroplasia with mixed inflammatory infiltrate was observed. Focal areas of edema, emphysema, and hemorrhages were observed in the alveoli. The same necrosuppurative exudate was present in the bronchi. Elastic fibers in the adventitia of the pulmonary arteries were degenerate and dissociated.
In this case, clinical and gross findings, their anatomical location, and microscopic lesions were compatiblewith thosereportedinCVCTincattle(BREEZE et al., 1976; GUDMUNDSON et al., 1978; BRAUN, 2008; CULLEN \& STALKER, 2015; CONSTABLE et al., 2017a). No other lesions compatible with ruminal lactic acidosis or other conditions were observed during postmortem examination and histopathological analysis. However, focal rumenitis could not be completely ruled out because the entire ruminal wall was not evaluated and the cause of the pathology could have been missed. Nevertheless, the presence of liver abscesses and exposure of highly fermentable foods such as wheat grain and ground corn allowed us to presume that the animal had ruminal acidosis. (PLAIZIER et al., 2007; ENEMARK, GARRY \& McCONNEL, 2015).

Additional tests, including ultrasonography between the eleventh and twelfth right intercostal space, chest X-rays, hematology analysis, and blood chemistry (BRAUN et al., 2002; BRAUN, 2008; SIGRIST et al., 2008) can be useful to confirm the ante mortem diagnosis, though they are rarely used. Hepatic abscesses occured in feedlot cattle consuming high-concentrate diets; although, resultant clinical disease with CVCT is rare. However, in dairy herds where cows also received diets rich in grains, CVCT is more frequently reported. This may be due to more prolonged dietary exposure over the longer lifespan of the animal. However, due to its short clinical course, nonspecific clinical signs, and high lethality, CVCT may be underdiagnosed.

Treatment is generally unsuccessful (GUDMUNDSON et al., 1978; DIVERS \& PEEK, 2008a; WOOLUMS, 2015); although, SIGRIST et al. (2008) reported a successful treatment in an affected cow. A better approach is prevention by reduction of the incidence of ruminal lactic acidosis in highproduction dairy cows, including periodical control feeding practices such as amount, type, composition and structure of grains and fibers, feeding frequency and degree of adaptation. Similarity, the evaluation of the equipment used for mixing and distribution of the food is a strategy that should be also include. In addition, a gradual acclimatization of the rumen to the diets could be done, mainly in the early lactation cows, transition cows and pre-calving cows and heifers. Buffers such as sodium bicarbonate and magnesium oxide and antibiotics such as monensin or lasalocid have given good results too (DIVERS \& PEEK, 2008b, ENEMARK, 2009; GARRY \& McCONNEL, 2015, CONSTABLE et al., 2017b). Other approaches for detection of ruminal acidosis included the clinical evaluation of the history or sins 


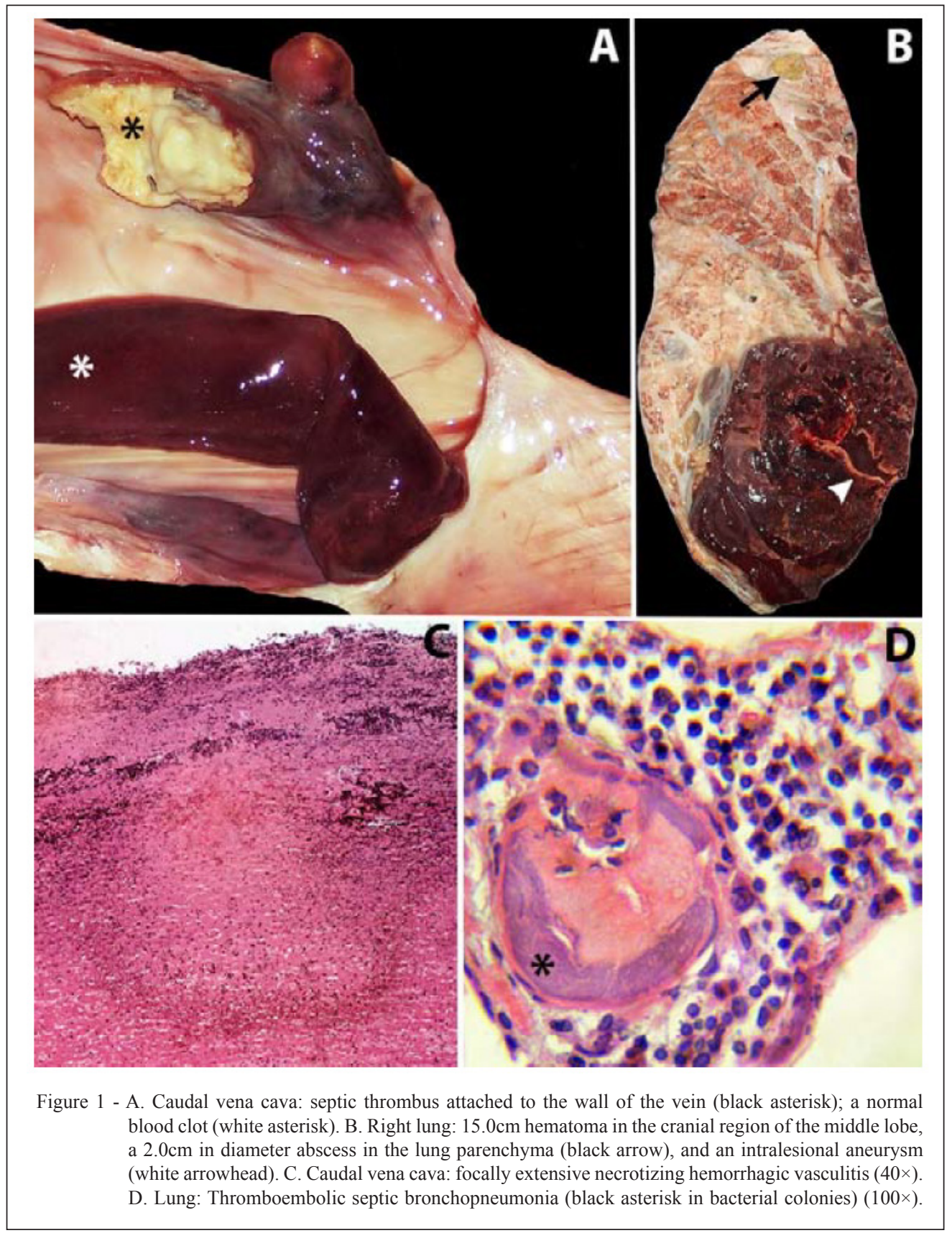

of diarrhea, anorexia, depression, dehydration, along with evaluation of conditions in which they could occur, as well as food intake and milk production.

In Argentina and Uruguay, the incidence and economic losses due to CVCT are unknown and should be determined by prospective studies. Finally, CVCT should be included in the differential diagnosis of clinically affected animals that show signs of acute respiratory disease (BREEZE et al., 1976; MILLS \& PACE 1990; BRAUN, 2008, WOOLUMS, 2015).

\section{ACKNOWLEDGEMENTS}

The authors thank Lilian Lischinsky (INTA EEA Balcerce, Buenos Aires, Argentina) for the histological processing of the tissue samples. Part of this work was funded by the Research Project INTA PNSA-1115054.

\section{REFERECES}

BRAUN, U. et al. Diagnosis by ultrasonography of congestion of the caudal vena cava secondary to thrombosis in 12 cows. 
Veterinary Record, v.150, p.209-213, 2002. Available from: <http:// veterinaryrecord.bmj.com/content/150/7.toc $>$. Accessed: May 12, 2016. doi: 10.1136/vr.150.7.209.

BRAUN, U. Clinical finding and diagnosis of thrombosis of the caudal vena cava in cattle. Veterinary Journal, v.175, p.118-125, 2008. Available from: $<$ http://www.sciencedirect.com/science/article/pii/S109002330600253X > Accessed: May 12, 2016. doi: 10.1016/j.tvj1.2006.11.013.

BREEZE, R.G. et al. Pulmonary arterial thrombo-embolism and pulmonary arterial mycotic aneurysms in cattle with vena cava thrombosis: a condition resembling the Hughes-Stovin syndrome. Journal of Pathology, v.119, p.229-237, 1976. Available from: <http:// onlinelibrary.wiley.com/doi/10.1002/path.1711190407/abstract;jsessio nid=145D52C1DBA6E9745DDD8142F54D292F.f04t01>. Accessed: May 12, 2016. doi:10.1002/path.1711190407.

CULLEN, J.M.; STALKER M.J. Thrombosis of the caudal vena cava. In: Jubb, Kennedy \& Palmer's Pathology of domestic animals. 6.ed. St Louis: Elsevier, 2015. V.2, Chapt.2, p.298-299.

DIVERS, T.J.; PEEK, F.S. Caudal vena cava thrombosis. In: Divers T.J, Peek F.S. Rebhun's diseases of dairy cattle. St. Louis: Elsevier, 2008a. Part II, Chapt.4, p.111- 114.

DIVERS, T.J.; PEEK F.S. Subacute to chronic rumen acidosis. In: Divers T.J, Peek F.S. Rebhun's diseases of dairy cattle. St. Louis: Elsevier, 2008b. Part II, Chapt.5, p.134-135.

ENEMARK, J.M. The monitoring, prevention and treatment of subacute ruminal acidosis (SARA): a review. Veterinary Journal, v.176, p.32-43, 2009. Available from: < http://www.sciencedirect.com/science/ article/pii/S1090023307004224>. doi: 10.1016/j.tvj1.2007.12.021.

GARRY, F.; McCONNEL, C. Indigestion in ruminants. In: SMITH B.P. Large animal internal medicine. 5.ed. St Louis: Mosby, 2015. Part 5, Chapt.32, p 777-799.

GUDMUNDSON, J. et al. Pulmonary thromboembolism in cattle due to thrombosis of the posterior vena cava associated with hepatic abscessation. Canadian Veterinary Journal, V.19, p.304-309, 1978. Available from: <https://www.ncbi.nlm.nih.gov/pmc/articles/ PMC1789505>. Accessed: May 12, 2016.

IKAWA, H. et al. Bacteriology of caudal vena cava thrombosis in slaughter cattle. Veterinary Record, v.120, p.184-186, 1987. Available from: $<\mathrm{http} / /$ veterinaryrecord.bmj.com/content/120/8A.toc $>$. doi: 10.1136/vr.120.8a.184.
JENSEN, R. et al. Embolic pulmonary aneurysms in yearling feedlot cattle. Journal of the American Veterinary Medical Association, v.169, p.518-520, 1976.

MILLER, L.M.; GAL, A. Thrombosis of the caudal vena cava. In: ZACHARY J. F. Pathologic basis of veterinary disease. 6 . ed. St Louis: Elsevier, 2017. Section II, Chapt.10, p.606.

MILLS, L.; PACE, L.W. Caudal vena cava thrombosis in a cow. Journal of the American Veterinary Medical Association, v.196, p.518-520, 1990.

PLAIZIER, J.C. et al. Subacute ruminal acidosis in dairy cows: the physiological causes, incidence and consequences. Veterinary Journal, v.179, p.21-31, 2009. Available from: <http://www. sciencedirect.com/science/article/pii/S1090023307004315>. doi: 10.1016/j.tvj1.2007.12.016.

CONSTABLE P. D. et al. Caudal vena caval thrombosis (posterior vena caval thombosis) and embolic pneumonia in cattle. In: Constable P. D., Hinchcliff K.W., Done S. H., Grümberg W. Veterinary medicine, a textbook of the diseases of cattle, sheep, goat, pig and horses. 11. ed. St Louis Missouri: Elsevier, 2017a. Volume 1, Chapt.12, p.902-903.

CONSTABLE P. D. et al. Acute carbohydrate engorgement of ruminants (Ruminal lactic acidosis, rumen overload) and subacute ruminal acidosis. In: Constable P. D., Hinchcliff K.W., Done S. H., Grümberg W. Veterinary medicine, a textbook of the diseases of cattle, sheep, goat, pig and horses. 11.ed St Louis Missouri: Elsevier, 2017a. Volume 1, Chapt.8, p.461-472.

SIMPSON, K.M. et al. Caudal vena cava thrombosis following treatment of deep digital sepsis. Canadian Veterinary Journal, v.53, n.2, p.182-186, 2012. Available from: <https://www.ncbi.nlm. nih.gov/pmc/articles/PMC3258833>. Accessed: Aug. 20, 2016.

SIGRIST, I. et al. Antemortem diagnosis of caudal vena cava thrombosis in 2 cows. Journal of Veterinary Internal Medicine, v.22. p.684-686, 2008. Available from: <http://onlinelibrary.wiley. com/doi/10.1111/j.1939-1676.2008.0084.x/full>. Accessed: Aug. 20, 2016. doi: 10.1111/j.1939-1676.2008.0084.x.

WOOLUMS, A.R. Vena cava thrombosis and metastatic pneumonia. In: SMITH B.P.: Large animal internal medicine. 5. ed. St Louis: Mosby, 2015. Part 5, C. 